(c) The Author(s), 2020. Published by Cambridge University Press. This is an Open Access article, distributed under the terms of the Creative Commons Attribution licence (http://creativecommons.org/licenses/by/4.0/), which permits unrestricted re-use, distribution, and reproduction in any medium, provided the original work is properly cited.

\title{
PERCEIVING THINGS IN THEMSELVES: ABŪ L-BARAKĀT AL-BAĠDĀDĪ'S CRITIQUE OF REPRESENTATIONALISM
}

\author{
FEDOR BENEVICH \\ Ludwig-Maximilians Universität, München \\ Email: benevich@lrz.uni-muenchen.de
}

\begin{abstract}
What are the proper objects of perception? Two famous responses to this question hold that they are either the images of extramental objects, that is, the way in which they appear to us (representationalism), or they are the objects themselves (direct realism). In this paper, I present an analysis of this issue by Abū l-Barakāt al-Bag̀dādī (d. 1164/65), a post-Avicennian scholar whose impact on the history of Islamic philosophy has been largely neglected. Abu l-Barakāt argued against the traditional Aristotelian-Avicennian epistemological dualism, which distinguishes between the sense-perception of material particulars and the conception of immaterial universals in terms of the perceiver and/or the structure of perception. In Abū l-Barakāt's own theory, all epistemic acts have the unified structure of direct relation between one and the same perceiver (immaterial soul) and the objects themselves - both material and immaterial. His main thesis is that having corporeal organs is not necessary for sense-perception. In the final section of the paper, I show that Abu l-Barakāt's critique of the Aristotelian-Avicennian tradition was received as a breakthrough in epistemology. It may have also determined the epistemological theories of two of the most important post-Avicennian Islamic philosophers: Faḩr al-Dīn al-Rāzī (d. 1210) and Šihāb al-Dīn al-Suhrawardī (d. 1191).
\end{abstract}

Résumé. Quels sont les objets de la perception? Deux réponses célèbres à cette question soutiennent que ce sont soit les images des objets extramentaux, c'est-à-dire la façon dont ils nous apparaissent (représentationalisme), soit les objets eux-mêmes (réalisme direct). Dans cet article, je présente une analyse de cette question par Abū l-Barakāt al-Bag̀dādī (m. 1164/65), un savant post-avicennien dont l'impact sur l'histoire de la philosophie islamique a été largement négligé. Abū l-Barakāt s'est opposé au dualisme épistémologique traditionnel aristotélicien-avicennien, qui établit une distinction entre la perception sensorielle des particuliers matériels et la conception des universaux immatériels, notamment en ce qui concerne le percevant et/ou la structure de la perception. Selon la théorie d'Abū l-Barakāt, tous les actes épistémiques ont la structure unifiée d'une relation directe entre un même percevant (l'âme immatérielle) et les objets eux-mêmes - matériels et immatériels. Sa thèse principale consiste à dire qu'avoir des organes corporels n'est pas nécessaire pour la perception sensorielle. Dans la dernière section de cet article, je montre que la critique d'Abū l-Barakāt de la tradition aristotélicienne-avicennienne fut considérée comme une innovation révolutionnaire en épistémologie. Cela peut avoir 
déterminé les théories épistémologiques de deux des philosophes arabes postavicenniens les plus importants : Faḩr al-Dīn al-Rāzī (m. 1210) et Šihāb al-Dīn al-Suhrawardī (m. 1191).

\section{INTRODUCTION}

Among the many tasks of epistemology is formulating a response to the question of the proper objects of our sense-perception, cognition, imagination, and other mental activities. One common response to this question is the claim that the proper objects of such activities are images (broadly speaking). These images may either be representations of real objects outside our minds or stand as our own independent phantasies. When I see a red apple, what I see is in fact the image "red apple": the red apple as it appears to me. Such an image may be corporeal or incorporeal or both - depending on our philosophy of mind and the mental activity in question. The core idea is that the object of perception ${ }^{1}$ belongs to $m e$. Someone else may simultaneously imagine "blue apple" instead of the red one. This theory is commonly referred to as representationalism. One opposing view holds that I perceive the red apple itself. That is, I perceive the extramental object as such. Mediation between the subject and the object of perception through mental entities and sense-organs becomes irrelevant in this theory. Another person may perceive absolutely the same red apple as I do. This is the core tenet of the epistemological position called direct realism. In addition to these positions, a third option presents itself, thanks to the work of Franz Brentano. I would situate this position between the other two. On the one hand, the proper object of perception is an image, such as "red apple". On the other hand, the pieces of information, such as "redness" and "being an apple", are said not of this image but of the red apple itself. This is because the representative image "red apple" is intentionally directed towards the apple itself. This position may be called intentionalism.

It has become custom in the history of philosophy to inquire whether a given philosopher was a representationalist or direct realist and to consider what his stance on intentionality was. Among the vast scholarship on Aristotle's epistemology, it appears that every imaginable position has been ascribed to Aristotle. The dominant view in contemporary scholarship seems to hold that Aristotle was a direct realist. This view opposes previous interpretations that described Aristotle rather as an

1 Throughout the paper I use the notion of perception in a broad sense of a cognitive act of any type in general, and not just sense-perception. 
intentionalist $^{2}$. Indeed, much of the ancient and medieval Aristotelian tradition attributed to Aristotle what we would today call a "theory of intentionality" and ascribed to this view themselves. To this tradition belongs, for instance, John Philoponus and Averroes, as well as - according to some interpreters - Avicenna ${ }^{3}$. Regarding the medieval period, debates rage in the scholarship over the question of whether Thomas Aquinas was a representationalist (or rather intentionalist) or direct realist $^{4}$.

It has been largely ignored, however that, half a century earlier than Thomas, in the eastern part of the Arabic speaking world, a debate occurred that closely resembled the contest of representationalism and direct realism. The central figure of this debate was Abū l-Barakāt alBağdādī (d. 1164/65), a Jewish scholar, who wrote in Arabic and who allegedly converted to Islam. Shlomo Pines and Jari Kaukua note in their studies of Abū l-Barakāt's psychology that he refutes the traditional Aristotelian-Avicennian doctrine of the powers or the faculties ( $\delta v v \alpha \mu \varepsilon \iota \varsigma$ / quwā) of soul. Instead he insists on the importance of the concept of a "self" that is identical to the immaterial soul. It is this "self", rather than a faculty of soul that dwells in a sense-organ, that is the proper subject of any kind of perception ${ }^{5}$.

In this paper, I will focus on the epistemological background of Abū

2 Most famous is the discussion of Aristotle's epistemology that occurred between Putnam, Nussbaum, Burnyeat, and Sorabji. It can be found in Martha Nussbaum and Amélie Rorty, Essays on Aristotle's "De anima" (Oxford: Clarendon Press, 1992). See also Christof Rapp, "Intentionalität und Phantasia bei Aristoteles", in Dominik Perler (ed.), Ancient and medieval theories of intentionality (Leiden-Boston-Köln: Brill, 2001), p. 63-95, and Victor Caston, "Aristotle and the problem of intentionality", Philosophy and phenomenological research, 58, 1998, p. 248-298.

3 Cf. Richard Sorabji, "From Aristotle to Brentano: The development of the concept of intentionality", Oxford studies in ancient philosophy, suppl. vol. 1991 "Aristotle and the later tradition", p. 227-259. On intentionality in Avicenna see Deborah Black, "Intentionality in medieval Arabic philosophy", Quaestio, 10 (2010), p. 65-81, Jari Kaukua, Avicenna on subjectivity: A philosophical study, PhD thesis (Jyväskylä University, 2007), and id., "The problem of intentionality in Avicenna", Documenti e studi sulla tradizione filosofica medievale, 25 (2014), p. 215-242.

4 Cf. Robert Pasnau, Theories of cognition in the later middle Ages (Cambridge University Press, 1997), and Dominik Perler, Theorien der Intentionalität im Mittelalter (Frankfurt am Main: Vittorio Klostermann Verlag, 2002), p. 80-89.

5 Shlomo Pines, "La conception de la conscience de soi chez Avicenne et chez Abu'lBarakāt al-Baghdādī's Poetics and Metaphysics", Archives d'histoire doctrinale et littéraire du Moyen Âge, 21 (1954), p. 21-98; Jari Kaukua, "Self, agent, soul: Abū l-Barakāt al-Baghdādī's critical reception of Avicennian psychology”, in J. Kaukua and T. Ekenberg (ed.), Subjectivity and selfhood in medieval and early modern philosophy (Springer, 2016), p. 75-89. 
l-Barakāt's reformulation of Aristotelian-Avicennian psychology. I will show that, in conjunction with some traditional arguments against representationalism, this psychology leads Abū l-Barakāt to accept a form of direct realism, which for the purposes of this paper I will call here "unified direct realism," and to dismiss any kind of epistemological dualism between conceptual understanding and sense-perception. In his view, one and the same immaterial soul - the first-person subject of perception - directly perceives both universal concepts and sensible particulars through the same epistemic procedure. As a result, Abū l-Barakāt suggests that, contrary to the tenets of the Avicennian tradition, one can in fact cognise sensible particulars without having recourse to the senses of the body, just as one can directly cognise intelligibles.

In this essay I will make the following points concerning Abū lBarakāt's "unified direct realism." In the first section, I will articulate Abū l-Barakāt's account of the rival view, representationalism. Then I will address two main lines of his counterargument. The first line (section two) focuses on the character of the proper objects of perception and appeals to traditional arguments grounded in the perception of distances and magnitudes. The second line (section three) identifies the proper subject of perception, the "self." This is where psychology meets epistemology and the refutation of the faculties of the soul plays a central role. In section four, I will ask how historically fair Abū l-Barakāt's criticism was and explain how his direct realism is intended to differ from the Aristotelian or Avicennian formulation of that position. In the fifth section, I will summarise Abū l-Barakāt's own doctrine and briefly speculate on how his unified direct realism might work. Finally, in conclusion, I will briefly show that Abū l-Barakāt's contemporaries explicitly acknowledged his importance for the history of epistemology in the Islamic world. I will hypothetically suggest that the most important philosophers of the twelfth century based their epistemologies on Abū l-Barakāt's "unified direct realism."

\section{ABŪ L-BARAKĀT'S RIVAL: REPRESENTATIONALISM}

The discussion of the proper objects and subjects of psychic and mental activities forms the core (more than $70 \%$ ) of the De anima section of The reconsidered, Abū l-Barakāt's magnum opus ${ }^{6}$. In this section, Abū

${ }^{6}$ As Pines has put it, Kitāb al-mu ${ }^{c}$ tabar literally means Le livre de ce qui a été établi par réflexion personnelle (Shlomo Pines, "Nouvelles études sur Awhad al-Zamân Abū-l-Barakât al-Baghdâdî”, Paris, Durlacher, 1955). I decided that this intention 
l-Barakāt discusses all of the views that have come down to him, such as extramissionist and intromissionist positions concerning the problem of vision, or different divisions and assignments of internal and external sense-faculties and sense-organs. Without explicating his analysis of every view presented, it suffices to say that Abū l-Barakāt focuses most extensively on a constellation of recurring notions and ideas that he finds particularly objectionable.

First, according to his reconstructions of their positions, Abū lBarakāt's predecessors frequently appeal to "resemblances" that occur to a sense-organ or sense-faculty of the perceiver (mudrik) when he or she perceives some extramental object. The notions for these resemblances are derivatives of the Arabic root $m-\underline{t}-l$ which literally means something like "being similar" and "resemble" (II.308.3). So, whenever we perceive something, there is a mitāl ("resemblance" or "image"). Alternative terms may be found, for instance, in Abū l-Barakāt's presentation of the intromissionist theory of vision: šabah ("figure"), hayāl ("imaginative object") and often șūra ("form") (II.324.5-6; II.333.8).

These "images" perform a certain action: they occur (hasala) in a sense-faculty or in a sense-organ (II.311.24). Further, in The reconsidered, we can find the traditional Aristotelian division between outer (hāriğa) and inner (bātina) senses. Abū l-Barakāt's summarising report contains the following notions that are traceable to Avicenna's famous revision of inner and outer senses: vision, hearing, touch, smell and taste for outer senses, and common sense, imagination (i.e. tahayyul), estimation, and memory for inner $\operatorname{senses}^{7}$ (II.323-24; II.340-41). Although Abū l-Barakāt recognises different inner senses, he does not seem to see any important difference between them and usually analyses them altogether as the senses of the brain. Thus, images in perception primarily occur either in the outer sense-organs, as for instance, when I touch the table and the sense of touch occurs in my hand, or in the brain, as when I imagine myself touching the table. Nevertheless, the

may be best rendered as The reconsidered, given that reconsideration usually implies careful analysis. Through this translation, I intend the idea that Abū l-Barakāt revises the idea of others. In what follows, I will refer to the volume, pages and line numbers of Yaltkaya's edition (Abū l-Barakāt al-Bağdādī, Kitā b al-mu tabar, ed. Şerefeddin Yaltkaya, 3 vol., Hyderabad, 1938) without mentioning the title.

7 On Avicenna's theory of internal and external senses see Deborah Black, "Imagination and estimation: Arabic paradigms and Western transformations", Topoi, 19 (2000), p. 59-75, and Peter Pormann, "Avicenna on medical practice, epistemology, and the physiology of the inner senses", in P. Adamson, Interpreting Avicenna: Critical essays (Cambridge University Press, 2013), p. 102-107. 
distinction between inner and outer senses does not play a role in $\mathrm{Abu}$ l-Barakāt's reconstruction of the rival position, as he recognises a pattern common to both of them. In both cases, one says that the objects of perception are imagined (tamattala), engraved (intaqaša fĩ), inscribed (irtasama) or impressed (intaba ${ }^{c} a$ ) in the corresponding sense-organ: brain, hand, eye, etc. (outer senses: II.308.3; II.324.20; inner senses: II.308.9; II.340.19; II.341.5).

Given these distinctions, the intromissionist theory of vision and the theory of common-sense are presented as follows:

As for the objects of vision, some ancients said about them that we only see them through the arrival of a figure, imaginative object, image, or a form of the observed to [the observer]. They talked about it in various ways. Whatever arrives [to the observer] does so by being impressed in the specific organ of vision (II.324.5-7).

They say that this [activity] is [performed] by engraving figures and images having colours and shapes in the two front ventricles of the brain; or rather in the spirit ( $a l-r \bar{u} h$ ) that exists in them. That which perceives them is a power that they call common sense (II.340.18-21).

So, any kind of perception - inner or outer - happens through the occurrence of an image of the perceived object in the corresponding organ. This however does not immediately entail representationalism. Indeed, in neither passage does Abū l-Barakāt claim explicitly that the imprinted images are the objects of perception themselves. The occurrence of an image in the sense-organ may be merely a means for perception. Neither direct realist nor intentionalist would deny this. The issue is, however, clarified in the following passage:

One says in respect of each among these perceptions that the perceiver "encounters" (yulāqā) the perceived and "talks" (yušăfihuhū) to it. The idea that unifies [all accounts of perception] is an encounter between the perceiver and the perceived, their coming together either by the perceiver or by the perceived. Yet they have [also] explained vision on the basis of how shapes having colours get engraved in surfaces, bodies, and mirrors, and how qualities, such as heat and cold, migrate by being relocated from some bodies to others. They said in respect of mental perceptions and imaginative activities that they [amount to] grasping forms and imagining figures in specific organs. These are the spirits which bear the powers [of soul]. They have however made an exception among these perceptions. It is that which they called intellectual perception. It does not specifically belong to any organ, nor does it require any organ. Whatever the perceiver encounters among [intelligibles], he perceives it through himself $(b i-\underline{d} \bar{a} t i h \bar{\imath})$ and he makes it occur in himself ( $f \grave{i} \underline{d} \bar{a} t i h \bar{\imath})$. [...] [325.9] According to these views, whatever is perceived - especially in the case of mental perceptions - pri- 
marily and essentially is not that which is said to be perceived because its meaning $\left(m a^{c} n \bar{a}\right)$ and image is imprinted [in the perceiver]. Rather it must be the meaning and the image [themselves]. It is not verified how the possessor of the meaning is perceived through it, or [maybe the perception of that object] is not verified at all (II.324.18 - 325.11).

This passage is central to Abū l-Barakāt's account of the view under attack. First, he collects all possible iterations of perception - both inner and outer - under the notion of "encounter" between the subject and the object of perception. With this, he does not have any qualms. Moreover, we will see in the fifth section that the central point of Abū l-Barakāt addresses this general notion of "encounter". He does not, however, assent to anything that is added to this notion. Here, we again find the language of "engraving" an image in the sense-organ: both in the case of inner and outer sense-perception. Towards the end of the passage, Abu 1-Barakāt finally charges his opponent with representationalism, as the account under consideration entails that one does not perceive the object itself. Yes, one does perceive the "meaning" and the "image" of an object, but one does not perceive that to which this meaning and this image belong. The last sentence says that the proponent of the "images" cannot articulate how the perception of images entails the perception of extramental objects, nor is it possible to verify that there are those objects at all. This point clarifies a central feature of representationalism. Representationalism entails not only that perception happens through simulacra of extramental objects, but also that these simulacra are the proper objects of perception. Abū l-Barakāt notices that this must specifically be the case for inner senses, which he here refers to as "mental perceptions." In cases of mental perception, we definitely lack the proper object of perception and only have recourse to an image.

Before we proceed to Abū l-Barakāt's counter-arguments, I want to draw attention to the exceptional case that Abū l-Barakāt mentions in the passage: the perception of intelligibles. In this case, one does not require the impression of a form onto a sense-organ. Rather the perceiver himself - that is, his immaterial soul - perceives intelligibles immediately and directly as occurring in himself. Abū l-Barakāt thus attributes to his opponents an important distinction between conceptual understanding and sense-perception. This amounts to a certain brand of epistemological dualism, according to which the epistemic relation to universal concepts is different from that to sensible particulars. Concepts belong to the space of our direct understanding, whereas material particulars do not. Rather the latter require some intermediary "image," 
which would substitute for them in someone's space of understanding and "encountering" the objects of perceptions. I will return to this fundamental dualism in section five.

\section{MAGNITUDES, DISTANCES, QUALITIES: AGAINST REPRESENTATIONALISM}

The position that Abū l-Barakāt ascribes to his opponents is representationalist. It maintains that all objects of our perceptions are certain images, merely ways in which things appear to us. No perceptual connection reaches the object of perception itself. Abū l-Barakāt does not struggle to find grounds upon which to criticise this position. He addresses first the outer senses and then the inner senses.

Abu l-Barakāt's analysis presents vision as the paradigm for the outer senses. In the case of vision, the intromissionist position stands for the general representationalist position concerning perception: we see things through the reception of an image in our eyes. Abu lBarakāt's main argument against this view appeals to the perception of magnitudes:

The decisive proof against those who believe in figures that arrive [into eyes] is for us to say: how can a pupil of eye or the spirit that is in it hold the impression of the form of heavens in accordance with its largeness and its magnitude, although [both] are much smaller than it? How can a large form be impressed in a small one (II.327.23 - 328.1)?

Since antiquity, opponents of the intromissionist theory of vision have appealed to this argument ${ }^{8}$. The problem is simple: if seeing something entails having an impression in the eye of the seer how can we account for seeing different magnitudes? Remember that this is a representationalist theory of perception. What we see is the picture in the eye and not the object itself. Given that we intuitively realise that we see the magnitudes of things, these magnitudes must be ascribed to the object of our perception. But the object of perception is a picture in the eye. Thus, this picture must actually be as large as the seen object itself. This is obviously problematic.

Abū l-Barakāt suggests a solution on behalf of his opponent. Perhaps the act of perception divides the seen object into small particles ( $\breve{u} u z^{\supset} a n$ sagi $\bar{r} r a n b a^{c} d \check{g} u z^{\supset}$ ), such that each of them can fit into the eye. Whenever we see something large, we rapidly see each of its small particles one by

8 Cf. Galen, On the doctrines of Hippocrates and Plato, ed. P. De Lacy (Berlin: Akademie Verlag, 1978), VII, 7. 4-15. 
one. Yet, Abū l-Barakāt responds: how do we see the entire object at all, rather than a series of particles? He imagines his opponent appealing to the Avicennian theory of common sense. One famous argument for this faculty notes that when it rains, we do not see every small drop falling. Instead, we see lines of rain. A similar phenomenon occurs when something quickly moves in a circle. We see a circle instead of this object at every discrete stage of its motion ${ }^{9}$. According to the theory under consideration, the same would apply to the perception of every object. Our common sense would aggregate the whole series of seen particles into one large thing. Abū l-Barakāt responds that this appeal to the Avicennian common sense does not solve the problem. Rather, it replaces it, for we can similarly ask now how a large object can fit into the brain, which is the sense-organ of the common-sense (II.328.2-23).

The apprehension of magnitudes is not the only problem for representationalists. Abū l-Barakāt argues that whenever we hear something, we can also perceive how far the source of the noise is. If hearing necessitated an impression of the sound-wave in the ear (similar to a picture in the eye in the case of vision) this would be impossible. The noise that occurs in the ear is always the same distance from us (II.334.4-11). Abū l-Barakāt invokes the argument from distances in the case of vision as well. The impressionist position may hold that there is first an impression in the eye and, subsequently, the transfer (naql) of this image to the brain, where it is perceived by another faculty (II.337-38). Here, Abu l-Barakāt protests: "Each of us knows with certainty that he sees the remote in accordance with it remoteness and the close in accordance with it closeness, everything in its place and not in the interior of his brain (II.338.12-13)." In other words, if the objects of vision are representations, regardless of whether perception manifests through their occurrence in the eye or through their transfer to the brain, one cannot account for knowledge of the locations of the real objects, since the places of their representations are in parts of human body.

The idea that outer sense-perceptions must in any case be transferred to the brain brings us to the problems connected with inner senses. The common sense, for instance, resides in the brain, or rather in the spirit ( $r \bar{u} h$ ) flowing through the brain. According to the opponents of Abu lBarakāt, all outer sense perceptions are gathered in the common sense, like when I both hear and see something. This however entails that the

9 Cf. Avicenna, Healing, De anima I.5, 44.13-15 (quoted after Avicenna, Al-šifă ${ }^{\supset}, A l$ $n a f s$, ed. F. Rahman as Avicenna's De anima being the psychological part of Kitāb al-shifa $\bar{a}^{\circ}$, London, Oxford University Press, 1959). 
problems concerning representationalism hold a fortiori for the common sense:

[A] We say the same about [the common sense] as we said about visual perception. There, one has denied that the shapes of anything having large dimensions (al-maqā dìr) would be inscribed [in the eye pupil] beholding its dimensions. So, how can thousands of such dimensions be inscribed in this small part [of the brain], how can a town be engraved [in the brain] beholding its measure, or a mountain beholding its largeness? Given that it was impossible in the case of an eye when it was seeing shape by shape, one after another, it is all the more impossible here, in the case of the perception of many different objects at the same time. How can different types of perceived objects such as colours, shapes, hotness and coldness, hardness and softness, [different] types of taste and smell be altogether? How does one move in shortest time from the perception of something to perceiving its opposite? [B] Also, if one's perception is the occurrence of those qualities in him, and the hot is that one in which there is hotness, and the cold is that in which there is coldness, and the hard is that in which there is hardness, and so on, then that spirit [which they claim to be the bearer of perception] hardens as stone, softens as air, becomes wet as water, becomes dry as earth, burns as fire, and becomes cold as snow in the shortest time period. Likewise it becomes sweet as honey and bitter as cactus, and [changes] in terms of these states from one opposite to another [almost] without any time distance (II.341.4-18).

First, Abū l-Barakāt again invokes the argument from magnitudes. In the case of vision, representations of mountains must possess information about the magnitude of the mountain in order for us to perceive that magnitude at all. Given that we perceive representations alone, information about the magnitude reverts on representations, and the attributes of magnitude are applied to them. Now, the case of the common sense provides even bigger problems. The common sense must be suitable for all shapes of varying magnitudes to fit into it. If we, however, describe perception through the common sense as the observation of transferred images in the brain, these images must be as big as what they represent. When I say "This mountain is so-and-so big", the "mountain" is an image in my brain, and hence "so-and-so big" applies to something in the brain. Obviously, this leads to problems.

It is quite central for understanding Abū l-Barakāt's criticism of representationalism that his representationalist opponent believes that the representations that inhere in bodies are corporeal entities (see also section four). So, in the second part (part B) of the argument, Abū l-Barakāt has additional means to attack the idea that representations occur in sense-organs. If the occurrence of a representation of heat entails a phys- 
iological change just like when heat occurs in anything else, then my brain should become hot whenever I imagine fire. Again, the common sense unites all possible perceptions and constantly jumps from one to another. Hence, the problem holds for it a fortiori.

Summarising Abū l-Barakāt's critique of representationalism, one may trace the following logic. Whenever we perceive something, we have an object of perception. In perceiving this object of perception, we ascribe different attributes to this object. There are, however, some attributes that just cannot be ascribed to representations if we define them as corporeal simulacra, forms, images, and shapes that physically inhere in our bodies. Saying that my eye becomes yellow when I see something yellow and therefore I see the yellowness in the eye may not be such a problem ${ }^{10}$. Saying the same about attributes, such as magnitudes, distances, and some other corporeal qualities, is, however, quite problematic. Therefore, we must conclude that the object of perception to which these attributes belong is something beyond our bodies. Hence, the proper objects of perception are not representations but are rather the objects themselves. Surprisingly, this argument does not apply to outer sense-perception alone. Abū l-Barakāt quite explicitly denies the claim that, in the case of imagining things, the imagined entities are corporeal images that inhere in some brain ventricles. One may naturally ask what and where the imagined entity is in this case. Abū l-Barakāt resolves this issue by introducing the unitary subject of all perceptions, the immaterial "self."

\section{THE FIRST-PERSON SUBJECT OF PERCEPTION: THE IMMATERIAL SELF}

Determining proper objects of perception as extramental objects themselves is only the first step in Abu l-Barakāt's criticism of his predecessors' theory of perception. He understands the proper determination of the subject of perception to be integral to his project as well. Abū l-Barakāt wants to identify an immediate relation between one and the same subject of perception, the immaterial "self," and the multifarious objects of perception - whether imagined or real. In opposition to this immediate relation stands the traditional Aristotelian-Avicennian theory of powers and faculties of soul $(q u w \bar{a})$ that dwell in corporeal

10 As argued in Richard Sorbaji, "Intentionality and physiological process: Aristotle's theory of sense-perception", in M. Nussbaum and A. Rorty (eds), Essays on Aristotle's "De anima", p. 195-226. 
organs. Hence, Abū l-Barakāt's project demands a critical engagement with this theory of powers.

As Jari Kaukua and Shlomo Pines have already noted, Abū l-Barakāt develops Avicenna's psychological theory. This theory states that we have a direct intuitive grasp of our selves, which are identical to our immaterial souls. The most famous example of this theory is the "flying man" argument: we can imagine ourselves not having awareness of our corporeal organs and corresponding sense-perception. But we would still be aware of our "selves". Avicenna argues that this shows that our soul - being identical to our "selves" - is incorporeal ${ }^{11}$. This immediate access to the self plays an important role in Avicenna's argument for the unity of soul, as well. Although we perceive different objects with different faculties, these perceptions are necessarily united by one and the same subject, the self, which says: "I have seen and I got angry"12" (cf. Salvation, 389.14). Kaukua has rightly pointed out that Abū l-Barakāt develops this line of reasoning further, since he thinks that believing in distinct faculties of the soul is incompatible with establishing the unity of perception ${ }^{13}$. His programmatic statement goes as follows:

It suffices now to refute whoever talks about multiple powers and their being distinct from each other to become verily aware from us ourselves ( $\min$ anfusina $\bar{a}$ ) of the fact that it is [something] one and the same in us that sees, hears, thinks, deliberates, calls to mind, remembers, wishes, dislikes, is pleased, and is angry. Its self $(\underline{d} \bar{a} t u h \bar{u})$ and its thatness (anniyyatuh $\bar{u})$ are always one in all actions. There is no distinction in it. [...] [318.15] If it is the visual power that sees and it is something other than "me" - that is, other than my soul and my self - then it is something other than me that sees, not "I". Yet $I$ am aware, $I$ see, and I certainly and truly know that it is me who sees, hears, says, acts. If [the power] sees together with me and I [see] together with it - each of us on its own, being independent from another in terms of [this] act [of seeing] - then I do not require [the power for seeing]. It is however we who are aware and say that $w e$ see and not that something else sees. And everything numerically different is something else. If [the visual power] sees and transfers the seen to me, and then I see it through

11 Cf. Thérèse-Anne Druart, "The soul and body problem: Avicenna and Descartes", in T.-A. Druart (ed.), Arabic philosophy and the West: Continuity and interaction (Washington, D.C.: Center for Contemporary Arab Studies, Georgetown University, 1988), p. 27-49; Michael Marmura, “Avicenna's 'flying man' in context”, Monist, 69 (1986), p. 383-95; Peter Adamson and Fedor Benevich, "The thought experimental method: Avicenna's flying man argument", Journal of the American Philosophical Association, 5 (2018), p. 1-18.

12 Quoted after Avicenna, Al-nağāt min al-ġarq fì baḥr al-dalālāt, ed. M. Dānišpažūh (Tehran: Dānišgāh-i Tihrān, 1985).

13 Kaukua, "Self, agent, soul", p. 78-80. 
[this power] and in it, it also must be transferred to me that it occurred in [that power] as well as that [the seen] was transferred from [that power] to me. Then [this power] is receptive ( $q \bar{a} b i l a)$ and not active $\left(f \bar{a}^{\circ} i l a\right)$. It is the subject of inherence for the vision. It is matter (hay $\bar{u} l \bar{a})$ and not an active power. Or I am not aware of its act [of seeing]. There is then no difference for me whether the perceived is transferred to me while [the power] is not perceiving it, or it is transferred to me while the power is perceiving it, or I perceive it in [the power] (II.318.6-23).

This passage begins with Abū l-Barakāt's main argument. We intuitively know that we are the agents of our perceptive acts. The act of seeing something is undoubtedly ascribed to the first person and not to any third person, "something else." This something else may be a power of our soul or something different. Most importantly, it is not us. This is Abū l-Barakāt's central idea, to which he returns throughout his analysis of perception (cf. II.314.7-9; II.319.14-15; II.319.20-21; II.333.15-16; II.403.21-24; III.87.1-5). Given that he also accepts the logic of the "flying man" argument (II.306.2-5), his argument thus results in the claim that we intuitively and certainly know that the immaterial soul is the proper subject of perception rather than any faculty residing in the body (notice the famous ambiguity of the Arabic language where "soul" and "self" is just one and the same word nafs).

In light of the intuition of first person perceptive agency, the task of the faculties of soul becomes rather unclear. Abū l-Barakāt ascribes to his opponent the view that the faculties of soul are something numerically distinct from the immaterial self of the soul itself. These faculties, residing in their corresponding sense-organs, are the primary subjects of perception: when I see a red apple, the corporeal representation "red apple" occurs in the eye and is perceived by the faculty of vision. Abū lBarakāt argues that the act of perception becomes doubled on this view. First, the faculty sees something, and then it transfers the seen to the "self" that sees it once again. In the second part of the passage, Abu lBarakāt raises problems for this account. He claims that, according to this account, we would need to perceive the faculties' acts of perception as well, or at least the process of transferring the object of perception to the inner eye of soul, since we perceive the representations located in those faculties. Obviously, this is not the case. Whether a certain faculty of soul perceives something is completely irrelevant for the perception of soul itself. The soul only knows that there is an object of perception in front of it, regardless of whether this object was transferred to it through the sense-faculties.

Although it is not entirely clear towards the end of the passage which 
options Abū l-Barakāt identifies as false, one may suggest that his entire argument is grounded in the denial of any active $\left(f \bar{a}^{\circ} i l\right)$ involvement of so-called "powers" that dwell in sense-organs. The result would be that the transfer through the sense-organs is merely passive ( $q \bar{a} b i l)$. For instance, in his analysis of vision, Abū l-Barakāt not only denies the intromissionist thesis but the extramissionist as well (that we see objects through the rays that emit out of our eyes). According to Abū l-Barakāt's account of extramissionist theory, this theory would claim that there is a faculty of vision in this ray that reaches out towards the seen object. Abū l-Barakāt confronts this view with a dilemma. This power may be numerically identical with our soul. Our soul then leaves our body, flies over to the seen object, and returns. The only problem is that when soul leaves body, the body dies. Alternatively, this faculty may be numerically distinct from our soul. This however violates the first-person intuition (II.328.26 - 329.4; II.332-33). Though Abū l-Barakāt does, in fact, endorse the emission of rays, on his account, the ray "does not perceive itself, nor is there anything in it that perceives. Rather it is [merely] receptive ( $q \bar{a} b i l)$, a bearer ( $h \bar{a} m i l)$ that arrives at the [real] perceiver (II.326.4-5)."

More generally, Abū l-Barakāt's agenda is to deny that senseperception involves the active participation of anything other than the first-person subject. "Being active" means, in this case, to be the subject of perception. This understanding of being active does not rule out the possibility that sense-organs - that is, human body - passively participate in perception as well. This becomes central to Abu 1-Barakāt's analysis of inner senses. We saw in the previous section that Abū l-Barakāt denies that inner sensation, for instance imagination or the common sense, involves the "impression" of material images in the brain. Where then are the objects of imagination? The perceptual objects of the outer senses are outside our minds in the world, but imaginative things cannot be there. Abū l-Barakāt's answer is that the objects of inner sense are also directly related to the first-person subjects. Moreover: "[Mental forms] are in our selves, which we clarified to be non-corporeal substances (II.397.8-9);" "soul perceives [imaginative forms] through itself and in itself, and [they] can fit in it (II.351.1-2)." The last comment is fundamental to Abū l-Barakāt's argumentation. He previously argued that corporeal representations of large objects cannot fit in the brain. They can however fit in the immaterial soul, given that its immateriality permits everything to fit in it (II.352.11).

Why then do we have bodies for imagining things at all? Abu l- 
Barakāt initially presents a response that is rather detached from the problem. He tells a general story about the connection ( $\left.{ }^{i} i \bar{a} q a\right)$ of soul to body (II.344-45). He uses identifiably Platonic metaphorical language. Soul is in love ( ${ }^{c} i s ̌ q-$ II.351.14) with body, governs it (mulk II.345.3) and gets inspiration from it (ilhām - II.348.21). Being in love with body, soul sinks into (munhamika) it and turns its full attention (iltafat) to corporeal states (II.351.12-14). That is why body serves as an instrument ( $\bar{a} l a$ - the word in Arabic that means both "instrument" and "organ") for sense-perception: both in the case of outer perception, when soul turns its attention to eyes, and in the case of inner senses, when soul imagines something by turning to a certain part of the brain. Abū l-Barakāt insists that in neither case do we speak of perceiving an impression in a corporeal organ, eye or brain. These are mere instruments, which play a purely passive role: "Instruments / organs do not participate in [soul's] acts (II.348.24).”

The fact that sense-organs cannot be called the agents of perception does not foreclose the possibility that they are there for epistemic individuation ( $\left.t a^{c} y \bar{\imath} n\right)$ and specification (tahsș $\bar{s}$ ) of perception. After soul turns its attention to a certain sense-organ, it is this organ that determines what soul perceives (cf. II.347.14; II.348.17-24; II.351.9). One may wonder how this account of the individuation of sense-perception does not necessitate active participation in perception. Apparently, Abū l-Barakāt wants to distinguish between the act of perception as such and the corporeal process that underlies it. The sense-organ may well be the active principle of the second, but it cannot be the principle of the first. In any case, and most importantly, one should understand that when we imagine something by paying attention to certain part of the brain, the imaged object is not in the brain. Rather it is in us - that is, in our immaterial souls. Imagining something, the first-person subject turns to itself by using the corporeal organ - the brain - as an instrument.

There is one traditional Aristotelian-Avicennian inner sense that gives Abū l-Barakāt's theory particular trouble. It is memory. In the account attributed to his representationalist opponents, memory is a certain corporeal vessel in which images are stored. When we want to recall something we turn to this vessel and observe the image engraved in it. We have, however, seen that Abū l-Barakāt denies that any image can be impressed in the brain. All imagined things must inhere in the soul itself: "Memorising (hifz) these forms and meanings is by soul in it itself ( ${ }^{i n d a}$ nafs $f \bar{\imath} \underline{d} \overline{a t i h} \bar{a}$ ), which is not too narrow [for them] to fit in it (II.353.14-15)." This is, again, the argument from magnitudes that we 
saw in the second section. This however raises a natural concern: if our memories directly belong to the soul how are we not constantly aware of everything we learned? On this point, Abū l-Barakāt bites the bullet: we are aware of it! He draws a distinction between awareness as such and second-order awareness: awareness of awareness, or perception of perception (idrāk al-idrāk). It is this second-order awareness that is missing when we do not actively call memories to our minds.

Whatever is memorised is perceived by the one who remembers it although he is not aware that he perceives it, since he is preoccupied with something else and turns away from it. If he however perceives his perception by turning his attention to it, he is aware of it and recognises that he perceives it. Memory is perception, yet the [active] grasping of forms is perception together with the perception of perception (II.398.19-21).

The appeal to second-order awareness is among Abū l-Barakāt's favourite argumentative moves. As Kaukua has already noted, in his refutation of different powers active in our bodies, Abū l-Barakāt also confronts phenomena such as nutrition, or patients getting better or worse while they are asleep. In neither case is the person - the first-person subject, the immaterial soul - aware of what is happening (II.320). Should there not, therefore, be a different agent, a distinct power for these acts? Abū l-Barakāt denies this possibility. He argues instead that we are, in fact, aware of these acts. We just lack an awareness of our awareness (II.321). He compares this to the observation of the motion of the sun through the sky. If one constantly looks at the sun, one will not be aware of its motion, since our eyes follow its continuous slow trajectory. One only sees that the sun has moved to another place in the sky after turning away for some time and then looking at the sky again (II.315). The same applies to nutrition, digestion and other acts. We simply lack the awareness of ourselves being aware of these acts, since they are so slow and continuous ${ }^{14}$.

Thus, memories are stored immediately in our souls, and we simply lack the second-order awareness of them. In the metaphysics part of The reconsidered, Abu l-Barakāt once goes so far as to equate the phenomenon of self-awareness with the way in which we remember things. We are constantly aware of both, although we are usually distracted, and we can turn back by realising the second-order awareness (III.92.5-8). I think, though, that Abū l-Barakāt would still draw a certain distinction between two cases. For self-awareness does not require any involvement of body at all, as the "flying man" argument suggests. On the contrary,

$\overline{14}$ Cf. Kaukua, "Self, agent, soul", p. 81-87. 
as in the case of outer sense-perception and imagining, Abu l-Barakāt acknowledges that the brain serves as the passive instrument for the individuation of memory, not as a repository of engraved images but rather as a means of calling something to mind (II.352-353).

With this, Abū l-Barakāt establishes a consistent doctrine of the subject of any kind of psychic activity. The subject is the first-person "I," which is identical to the immaterial soul. Whenever we experience perception, an object presents itself to us. If the object involves sense-perception - inner or outer - then the body also serves as an instrument. The body, however, does not participate actively in perception. Abu l-Barakāt denies that there are any distinct faculties that dwell in sense-organs and that mediate the process of sense-perception.

\section{ABŪ L-BARAKĀT \\ AND THE ARISTOTELIAN-AVICENNIAN TRADITION}

We have seen so far how Abū l-Barakāt criticises representationalism and the notion of certain psychic powers that dwell in corporeal organs and perform acts of sense-perception. So far, however, the targets of Abu l-Barakāt's critiques have remained implicit. Although he mentions no names in this context (except III.70.22), appeals to the faculties of souls, the suggestion that some images occur in the sense-organs, and the particular analysis of concrete inner and outer senses leave no doubt that the target of Abu l-Barakāt's critique is the Avicennian theory of perception. Further, through Avicenna this critique implicates the whole Aristotelian tradition. Yet it remains to be considered whether Abū 1Barakāt's criticism of this tradition is historically fair.

At first glance, it may seem that all of the critical points that our author raises against Avicenna and the Aristotelian tradition emerge from a complete misunderstanding of their position. This is at least the case if one compares his readings with contemporary interpretations of Aristotle and Avicenna. Abū l-Barakāt ascribes to this tradition the idea that the primary objects of perception are corporeal imprints in our sense-organs. No modern interpreter of Aristotle would agree. First of all, Abū l-Barakāt completely ignores the famous claim in De anima II.12, 424 a 18 - 424 a 23 that we only perceive forms abstracted from matter. On this basis, several interpreters have ascribed to Aristotle the idea of intentionality: these forms would, in some way, be intentions that bear information about extramental objects ${ }^{15}$. Thus, neither the percep-

15 Cf. e.g. Michael Burnyeat, "Is an Aristotelian philosophy of mind still credible? A 
tion of magnitudes nor of distances would cause any problems, contrary to Abū l-Barakāt's claims. As mentioned in the introduction, scholars of Avicenna have ascribed the idea of intentionality to him as well, so he also escapes Abū l-Barakāt's criticism ${ }^{16}$.

Second, although some interpreters agree that the occurrence of representations in the sense-organs - of which both Aristotle and Avicenna certainly speak in their psychological works - involves physical change (like the position of Richard Sorabji ${ }^{17}$ ), they would never say that those corporeal representations are the objects of perception. Rather, perception consists in the occurrence of this image, the physiological process that follows upon it, and subsequently the perception of the extramental object itself. That is why it has been argued that Aristotle was a direct realist - no less than Abū l-Barakāt ${ }^{18}$. Although this interpretation has not yet been taken up by the modern interpreters of Avicenna, it was well known to medieval advocates of Avicenna's position. For instance, Nașīr al-Dīn al-Ṭūsī (d. 1274) argues in his commentary on Avicenna's Pointers and reminders:

Perception is not just the occurrence of a form in the organ. Rather it is its occurrence in the perceiver due to its occurrence in the organ. Therefore, perception occurs neither in the common sense, nor in the intersection of the two nerves [of eyes], but rather in the soul through both those organs due to the occurrence of the form in the two aforementioned places [i.e. organs] or some others (Commentary on Pointers and reminders, II.413.5-8) ${ }^{19}$.

If Ṭùsī is right in his interpretation of Avicenna, Abū l-Barakāt completely misses his target. Avicenna would never claim that the common sense, as a distinct faculty, perceives something that is physically imprinted in the corresponding sense-organ. Rather some formal representation inheres in the organ and thereby the perceiver - that is, Abu l-Barakāt's favourite first-person subject - perceives the object itself. On

draft", in M. Nussbaum and A. Rorty (eds.), Essays on Aristotle's "De anima”, p. 1526.

16 The "form without matter" solution has also become very popular in the thirteenth century Islamic East after Ațīr al-Dīn al-Abharī (d. 1264); cf. Ațīr al-Dīn al-Abharī, Kašf al-ḩaq $\bar{a}^{\supset} i q$ fì taqrīr al-daq $\bar{a}^{\curvearrowright} i q$, ed. by Hüseyin Sarıŏlu (Istanbul, 1998), p. 333, 1. 14-19.

17 Sorabji, "Intentionality and physiological process".

18 Cf. Rapp, "Intentionalität und Phantasia": given causal connection between the representation in the eye and the object itself, Rapp denies that there is any place for intentionality (because there can be no mistake in sense-perception). This amounts to a very strong form of direct realism.

19 Quoted after Nașīr al-Dīn al-Ṭūṣi, Šarh al-Išārāât, ed. by Ā. al-Āmulī, 3 vols (Qom: Mu’assasa-yi būstān-i kitāb, 2004). 
this account, Avicenna's theory seemingly does not differ from Abū lBarakāt's: there is an epistemic relation between the first-person subject and the object of perception itself whose physiological counterpart consists in the occurrence of some corporeal representation in the corresponding sense-organ.

We have also seen that Abū l-Barakāt extensively criticises an allegedly Avicennian theory of psychic faculties. He argues at length against the claims that they are distinct from the first-person subject of perception, and that they actively participate in perception. On Țūsī's interpretation, Avicenna does not assent to either of these claims. Why did Abū l-Barakāt decide that, according to Avicenna, the psychic faculties must be numerically distinct from the immaterial soul? Moreover, even if his reasoning about the active participation in perception applies to inner senses to some extent, as Avicenna acknowledges that they are active, Abū l-Barakāt completely ignores Avicenna's frequent assertion that outer sense-perception is purely passive ${ }^{20}$. Just as Abū l-Barakāt wants it to be.

These apparent interpretive shortcomings may suggest a distinct, underlying agenda in Abū l-Barakāt's proofs of direct realism. Indeed, his goal is not just to establish direct realism as such, but rather a certain kind of direct realism to which neither Aristotle nor Avicenna would agree. The reason is that Abū l-Barakāt wants to establish a form of direct realism in which any kind of perceptual activity - whether it be conception or inner or outer sense-perception - can arise between the "self" of the perceiver and the object itself independent of whether the "self" is embodied or not. That said, this doctrine of unified direct realism is not compatible with mainstream Aristotelian direct realism. On the contrary, assuming that the Aristotelian-Avicennian philosopher does espouse direct realism, he still would never agree with Abū l-Barakāt's claim that sense-perception can happen without obtaining corporeal representations in corporeal organs.

On this point, Abū l-Barakāt certainly does hit his target. There is no doubt that Avicenna claims that only something corporeal can perceive something corporeal. In his Salvation for instance, Avicenna argues that one can perceive something particular only through a corporeal organ (349.11). He takes it to be obvious that this must be the case in instances of outer sense perception: "Some present existent body can only be present and existent for some [other body] (350.5-6)." Nor can something that is in a place present itself to something that is not in a

20 E.g. Avicenna, Healing, De anima, I.5, 43.16. 
place (350.8). Less obvious is his claim that one requires a body for inner sense-perception. Avicenna's thesis, however, is that "one cannot imagine [anything] without an imaginative form being inscribed in the body (350.13-14)." Avicenna argues for this conclusion at length. In short, he suggests that we imagine two equal squares being juxtaposed with another square in between them. Avicenna argues that we imagine the different positions of the two squares neither because of their nature, nor because of some accidental state imposed (farada) upon them, nor due to a reference to any extramental squares. Thus, their distinct positioning in our imagination can be only explained by the divisibility (inqisām) of the underlying subject of the imagined picture. This subject is a corporeal organ or a sense-faculty that dwells in a divisible corporeal organ (351-354). In the next chapter of the Salvation, Avicenna discusses the opposite case: whatever is the subject of the conception of intelligibles cannot be something corporeal. As in several other arguments, the idea of divisibility plays a central role. This time, were a corporeal subject of intellection divisible, this divisibility would render the inherent intelligible divisible as well. Yet Avicenna cannot accept this result, as he maintains that intelligibles do not have measure (358.5-9).

Avicenna thus establishes that just as conception and senseperception differ in kind, so too they must be the activities of different faculties. Only the immaterial mind can perceive universals. Only the faculties of soul that dwell in corporeal organs can perceive sensible particulars. These relationships hold when presented with reversed priority, as well. If something is the object of mind's awareness, it must be universal. If it presents itself to a sense-faculty, however, it must be a sensible particular. Abū l-Barakāt refutes this distinction. Two chapter titles in the De anima of The reconsidered speak for themselves: "That which perceives intelligibles and sensibles in us is one and the same" (II.400.16-17) and "The refutation of their statement that the intellect does not perceive particulars and sensibles (II.413.10)." In his refutation, Abū l-Barakāt's primarily targets Avicenna's argument from division:

It is on the basis of their argument that whatever is indivisible does not inhere in the divisible, and the form of whatever is divisible does not inhere in the indivisible, that they forbade that the perceiver of intelligible forms is the same as the perceiver of sensibles (II.403.6-8).

Abū l-Barakāt's counterargument is threefold. First, he suggests a distinction between a real division ( $q i s m$ wuğu $\bar{u} \bar{l}$ ) and division imposed by the mind (qism fardīi). Abū l-Barakāt apparently maintains that, in 
his analysis of the squares example, Avicenna was too quick in rejecting the possibility that the difference between the squares is merely mentally imposed (farada). Abu l-Barakāt's argument is that a mindimposed division in the object of perception does not entail the real division of the subject of perception ${ }^{21}$ (II.402-403).

Abū l-Barakāt's second line of argument addresses Avicenna's claim that something corporeal or in-place cannot be present in something incorporeal or not-in-a-place. Abū l-Barakāt appeals to the example of light. He takes the claim that light is not a body to be uncontroversial. Yet light inheres in bodies and travels through them. It is accidentally in place, and it is accidentally divided through bodies, but neither of these attributions belongs to the light per se. So, light is not corporeal and is not in-a-place but is present in something corporeal and in-a-place (II.404.11-15; III.86.16-19).

Thirdly, Abū l-Barakāt turns Avicenna's logic against him. First, if only the corporeal can inhere in the corporeal, then it becomes unclear for Abū l-Barakāt how Avicenna can claim that soul, being immaterial, is in a body (III.86.20-21). Further, Abū l-Barakāt notices that positing corporeal impressions in sense-organs does not really help Avicenna if one accepts his reasoning. How can the immaterial soul perceive this impression given that the impression is no less corporeal and sensible than the extramental object itself was (II.414.24 - 415.1)?

Thus, Abū l-Barakāt refutes the Avicennian thesis that the perception of sensibles requires the involvement of "a corporeal power by which they mean that it subsists in the body" (II.338.4). Note that Abū l-Barakāt insists that these powers are "corporeal" for his opponents, meaning that they are necessarily connected to corresponding organs. This is apparently the main reason why he ascribes to his opponent the view that the faculties of soul must be numerically distinct. They are corporeal, whereas soul is immaterial. Elsewhere, Abū l-Barakāt rejects the possibility that the soul's faculties are parts of soul, because this would violate the unity of perception (II.353). If, however, these faculties are just the soul itself (without partition), then it is the soul which perceives sensibles. In this case, the mediation of corporeal senseorgans and corresponding faculties becomes unnecessary (II.338.19-23). This is precisely the position that Abū l-Barakāt himself maintains. It

21 Avicenna has a response to this solution in the Healing, De anima IV.3, 190.17 192.3: such imposing would be conceptual, but imagination does not involve anything conceptual. I am grateful to Jari Kaukua for bringing Avicenna's response to my attention. 
is opposed to the view that sense-perception requires sense-organs. Avicenna may come out as a direct realist on Țūsîs interpretation, but he would still insist that direct sense-perception requires having corporeal organs as means for it. Abū l-Barakāt denies this: there can be a direct acquaintance between the immaterial soul and extramental and mental sensible particulars. While this acquaintance can be mediated through the body, it need not always be so:

[The soul] turns its attention to whatever has been individuated and specified through an organ not because [otherwise] it would be impossible for it by its essence and nature [to perceive sensibles]. Rather [the reason for its using body] is a connection of character and inspiration and its custom (II.348.20-21).

Abu l-Barakāt argues that the soul - that is, the first-person subject uses body not because it otherwise would be unable to perceive sensibles. There is nothing in the nature of the immaterial soul that would exclude this, as we have seen that Abū l-Barakāt rejects Avicenna's argument from indivisibility. The only reason that soul uses body is the "connection of inspiration," which we saw already in the third section. Sense-organs are thus merely responsible for individuation of sense-perception and not for the whole process of sense-perception as such. This explains why Abū l-Barakāt was so insistent that they play a completely passive role. His intention was not to refute the idea that the faculties of soul that dwell in organs are all active (which no one would actually maintain). Rather he wanted to deny that these faculties can in any way be considered the subjects of perceptions. Abū l-Barakāt apparently believes that Avicenna is forced to accept this view, given his argumentation in the Salvation that corporeal faculties are necessary for sense-perception: if they did not actively participate in perception one could eliminate them and still have the perceptual relation between the immaterial subject and the object of perception. Since one cannot eliminate them according to Avicenna, they must be the agents of perception.

Hence Abū l-Barakāt's main intervention is his claim that these faculties and corresponding organs are not necessary conditions for our awareness of sensible particulars. In the end of the passage quoted in the third section, Abū l-Barakāt argues that, since we do not perceive that our organs perceive, it does not make any conscious difference to us as perceivers whether the sense-organs were involved in perception. $\mathrm{He}$ may be confusing the opaque and transparent contexts here (they may be involved in sense-perception although we do not perceive it). Nevertheless, Abū l-Barakāt apparently thinks that this argument is sufficient 
to conclude that corporeal sense-organs and the corresponding faculties of soul are not necessary conditions for sense-perception.

The arguments from magnitudes and distances that we saw in the second section follow the same trajectory. Abū l-Barakāt elicits them to refute the understanding of sense-perception that identifies the occurrence of corporeal images in sense-organs as a necessary condition for sense-perception. In fact, Abū l-Barakāt takes these arguments even further than he took the line of reasoning that focused on the subject of perception. Indeed, he claims that, not only is the involvement of "corporeal faculties" that acquire inherent corporeal images not necessary, but it is impossible. Only the immaterial soul - the first-person subject can accommodate all imaginable and sensible particulars:

It has been verified and established many times in different and similar ways of expressing it that the perceiver of intelligibles is the same as the perceiver of sensibles and that the perceiver of concrete existents is the same as the perceiver of mental objects in us (II.416.6-8).

\section{UNIFIED DIRECT REALISM}

The outcome of Abū l-Barakāt's analysis of perception may be now summarised. First, he rules out possible candidates and finally identifies the proper object of perception. Based on his argument from magnitudes and distances, the proper object of perception cannot be a representation that occurs in sense-organs. Rather, the proper object of perception is the object itself. Second, Abū l-Barakāt establishes the proper subject for all forms of perception. On the basis of the first-person awareness argument, he argues that there is only one, unified subject for all forms of perceptions, which he calls the first-person immaterial "self." To strengthen his claim, Abū l-Barakāt then anticipates a possible counter-argument from the Aristotelian-Avicennian philosopher, which is the claim that the perception of material particulars cannot be obtained without the involvement of sense-organs. Abū l-Barakāt counters this claim by first acceding that sense-organs may indeed be involved in sense-perception; but this fact in itself does not automatically constitute a necessary condition for sense-perception. As a result, Abū l-Barakāt shows that they play no "active" role in sense-perception. With these two steps - namely, establishing the proper object and subject of perception - Abū l-Barakāt develops what I have called in this essay "unified direct realism." The main tenet of this form of unified direct realism is that there is no fundamental difference between conception and sense-perception. This is 
due to the fact that, according to Abū l-Barakāt, in both cases of cognitive activity we are dealing with a single process of epistemic connection between one and the same subject of cognition (the immaterial "self") on the one hand and different objects on the other, regardless of whether these objects are immaterial intelligibles, material imaginative forms, or sensible extramental particulars. To this Abū l-Barakāt adds that all epistemic activities have the same structure. Abū l-Barakāt calls it a mere "encounter" $\left(\operatorname{laq} \bar{a}^{\text {ग}}\right)$ between two objects themselves:

If we turn to our minds, [inspecting] this general idea that perception is complete and realised through the encounter between the perceiver himself

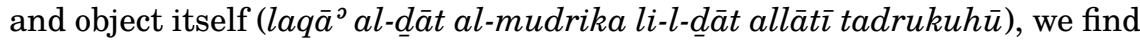
[this idea] to be correct (II.325.11-13).

"Encounter" thus is the notion upon which unified direct realism relies. By encountering the subject of perception basically "meets" the object of perception, like one man on the street meeting the other. Encountering is a sufficient condition for perception. Later, Abū l-Barakāt offers some linguistic analysis of the Arabic notion of perception (idrāk). It originally means that something or someone reaches or comes across something or someone else, just like when I go to a meeting and encounter someone there. Abū l-Barakāt does not see any significant difference between this general notion of $i d r \bar{a} k$ and the specific case when the encountered object is a perceived object (II.394.8-17). For in both cases someone reaches something: $i d r \bar{a} k$ understood as sense-perception is merely a special kind of that "reaching."

On this basis Abū l-Barakāt concludes that perception is a relational state (hâla id̄âfiyya), analogous to the way in which I encounter someone and we relate to each other as the one who was met and the one who met (II.323.14-15). This idea will become crucial in Abū l-Barakāt's solution to the problem of God's knowledge of perishing sensible particulars. Indeed, it will prove no less crucial than the aforementioned refutation of Avicenna's claim that one needs to be corporeal (which God is not) in order to perceive sensibles ${ }^{22}$ (III.83.3-4). This leads us to another related question, namely, whether Abū l-Barakāt might have thought that God - and also perhaps superlunary intellects - is the only case where an immaterial entity actually happens to be epistemically related to sensible particulars, or whether he thought that the human intellect could also know in this way. We have seen in the previous section that

22 Fedor Benevich, "God's knowledge of particulars: Avicenna, kalām, and the postAvicennian synthesis”, Recherches de théologie et philosophie médiévales, 76 (1), 2019, p. 1-47. 
Abū l-Barakāt definitely does not exclude this option in the case of human intellects even though he acknowledges that they factually happen to perceive sensibles through the passive involvement of sense-organs. That said, how humans could perceive sensibles without corporeal organs remains an open question ${ }^{23}$.

Thus, Abū l-Barakāt believes that all epistemic activity proceeds in the same way: perception is a relation between the first-person subject, the immaterial "self", and any kind of objects of perception. His doctrine of unified direct realism is significantly different from the traditional tenets of Aristotelian-Avicennian epistemology. On the one hand, Aristotle might have agreed that conception and sense-perception are alike in a certain sense (cf. De anima III.4, 429 a 13-17). Furthermore, Avicenna can also be interpreted as holding to the idea that all epistemic activity has the same basic structure, since for him all knowledge is based on an impression $\left(i n t i b \bar{a}^{c}\right.$ ) of perceptual objects in the perceiver. This is in fact how the later tradition understood him. Nevertheless, it would be misleading to say that Aristotle or Avicenna's idea of "knowledge" (in the broad sense) having the same epistemic structure is equivalent to Abu l-Barakāt's unified direct realism. The reason is that, as we have seen in the previous section, they require sense-organs to mediate in cases of sense-perception. While conception for them is an immediate epistemic connection between the first-person immaterial self and the intelligible

23 There are two further problems in Abū l-Barakāt's account for which he never proposes a solution, so far as I can see. The first is whether Abū l-Barakāt would accept that we can see with our ears or hear with our eyes, since our reliance on the correspondent organs of perception is not necessary according to him. The second problem is whether Abū l-Barakāt implies that we can see without eyes and hear without ears at all. Rather speculatively, I suggest that Abū l-Barakāt would deny that we can see with our ears. The essence of ears prevents us from seeing through them. If the soul turns its attention to a corporeal organ, in the sense of "a connection of inspiration" as described in the previous sections, it can only perform those activities that are compatible with the essence of the organ. Nor can the soul hear and see without ears and eyes if we understand hearing and seeing as processes which happen through ears and eyes respectively. Abū l-Barakāt's idea only is that we can acquire all information about particular individuals (which we normally acquire through eyes and ears) even without eyes and ears. Abū l-Barakāt means to grant that incorporeal substances can fully cognise sensible individuals, even if this cognition cannot be called seeing or hearing in the proper sense. I am grateful both for these questions and the discussion of responses to them to the participants of the "Theories of cognition in the Aristotelian tradition" conference, which happened in October 2019 in the University of Notre Dame London Global Gateway; especially to Colin King, Christopher Shields, Philip Neri Reese, Dominik Perler, and Klaus Corcilius. 
that is impressed on it, sense-perception requires mediation. For them, this mediation can be made through sense-organs and sense-faculties such that the first-person subject of perception is then connected to the object of perception. This mediation is necessary, furthermore, even in the case of inner perceptions such as imagination. This was for instance the main point of Abu l-Barakāt's criticism in the passage quoted at the end of the first section. We have seen there that he ascribes to his opponents a distinction between two cases: first, when one perceives sensibles, one requires the inscription and impression of representations in sense-organs; second, when one perceives immaterial intelligibles, one is entitled to talk of direct immediate perception (II.324.18 - 325.11). Abū l-Barakāt's own unified epistemology denies that there is any difference between conception and sense-perception.

Nor should one reduce Abū l-Barakāt's unified direct realism as a mere statement of the unity of the subject of perception. As I briefly mentioned in the third section, and as we have seen in Țūsìs interpretation in the fourth section, Avicenna might have been entirely willing to accept that the subject of all perceptions is one and the same: namely, the first-person "self" - the same one who feels anger is the same one who sees. Avicenna's idea here is however very different from Abū l-Barakāt's position that the perceiver of intelligibles is the same as the perceiver of sensibles. The reason is that Avicenna's statement of the unity of the subject of perception is still compatible with the idea that senseperception requires the involvement of sense-faculties in sense-organs. Abū l-Barakāt's thesis however is incompatible with that requirement.

In a slightly more generalising way I would suggest the following interpretation of Abū l-Barakāt's criticism of Avicenna's position. Basically, he confronts Avicenna with two options. If Avicenna accepts that the structure of conception and sense-perception is the same (in both cases the object of perception is impressed in the subject) he cannot hold the unity of the perceptual subject anymore. For while representations of sensible objects are impressed in a sense-faculty that dwells in a corporeal organ, intelligibles however, are impressed in the immaterial intellect directly. If however Avicenna instead wants to insist on the unity of the subject of perception, he cannot argue that conception and senseperception are similar epistemological processes. While conception is the impression of intelligibles in the immaterial "self", sense-perception is the impression of a representation in something other than the immaterial "self", namely a sense-faculty in a sense-organ. The first process 
is immediate, the second one is mediated ${ }^{24}$.

One might, furthermore, raise a number of doubts against Abū lBarakāt's unified direct realism. First, unified epistemology somewhat undermines the difference between the real and the ideal. Is there a way for a unified direct realist to account for the difference between that which is dependent on our minds (intelligibles and imaginative forms) and the mind-independent sensible particulars, given that both the subject of their perception and the way we perceive them is one and the same? Abū l-Barakāt seemingly makes his ground even shakier when he aligns the notion of perception with the notion of existence ( $w u \grave{g} \bar{u} d)$ :

If someone perceives something through one of his senses - such as vision, hearing, smell, taste, and touch - and he recognises it, and recognises that he has perceived it, he says about that thing that it is existent. By its being existent I do not mean that it is perceived, but rather that it is such that it can be perceived both before it has been perceived as well as after it, and before anyone else perceived it and after it. For something is in itself such that it can be perceived. Then, someone perceives it. Its being such is precisely what one calls existence (III.20.17-22).

Abū l-Barakāt shows in this passage how closely he sees the notions of perception and existence. Given that we perceive the object in itself, existence may be defined as something's being such that it can be perceived. In this passage, Abū l-Barakāt also attempts to foreclose a possible misunderstanding of his claim. This misunderstanding would ascribe a form of idealism to Abū l-Barakāt, suggesting that his claim that we perceive objects themselves, results in the conclusion that objects themselves only exist whenever we perceive them. Abū l-Barakāt roundly rejects this inference. Existence is not tantamount to being perceived. Existence is tantamount to being such that it can be perceived. Something exists and is such independently from its actually being perceived by anyone.

Although Abū l-Barakāt avoids falling into idealism, one may still wonder how he can account for subjective errors, given his unified direct realism. The strong side of Avicenna's position, that one requires sense-faculties in sense-organs for sense-perception, is that one could account for errors and misrepresentations by ascribing them to the active role of sense-faculties. For example, let there be a red apple in front of me. I however perceive it to be blue because my sense-faculty, residing

24 Avicenna's own way to grant the unity of perception is more nuanced than this. He uses the Neoplatonic theory of emanation: corporeal faculties emanate from the immaterial self (as procession); then they revert to it and transfer the acquired sensible information (as return) (cf. Healing, De anima, V.7, esp. 254.12). 
in a damaged sense-organ, actively misrepresents the red apple as blue and presents this false image to my inner first-person subject of perception. But this account is entirely wrong for Abū l-Barakāt. For him, sense-faculties in sense-organs are not necessary conditions for senseperception; as such, they cannot be used to explain the mistakes we make when conceiving and perceiving. Though Abū l-Barakāt would allow that our sense-organs specify sense-perception, they are merely passive principles. The red apple may appear blue to me, but there is no fault of the subject of perception in it, since the process is purely automatic. In fact, I did perceive the red apple; it only looked blue to me (as opposed to the theory that states that I actively misconceived the red-apple-data of sense-perceptions as blue apple). This might look very similar to the previous case in Avicenna. There is however a significant difference, which can be made evident on the basis of a more radical case: the perception of sensibles without the interference of bodies. We have seen that Abu l-Barakāt, as opposed to Avicenna, believes that this kind of perception is possible. But how can one account for subjective errors in this case? Does Abū l-Barakāt think that the immaterial perceiver can never make subjective mistakes?

We should not, however, worry that Abū l-Barakāt leaves too little space for the subjective. In his solution to this problem, he draws a distinction between perception and recognition $\left(m a^{c}\right.$ rifa). In his description of the states of knowledge acquisition, Abū l-Barakāt distinguishes seven levels:

(1) Mere awareness $\left(\check{s} u^{c} \bar{u} r\right)$ of something.

(2) Establishing (istit $b \bar{a} t$ ) it in the mind while being aware that one is aware of something (remember the importance of the second-order awareness for Abū l-Barakāt). This is called conceptualisation / imageformation (tasawwur).

(3) Learning to understand ( $f a h m$ ) the meaning of a concept when someone refers to it with a linguistic expression (lafz).

(4) Memorising ( $h a f z$ ) the learned idea.

(5) Recognition ( $m a^{c}$ rifa), which means that I see some object and recognise in it certain ideas that I have previously learned and memorised $^{25}$.

25 Note that $m a^{c}$ rifa traditionally has a broader meaning that includes both "cognition" and "knowledge". Abū l-Barakāt however insists on the idea of repetition in $\mathrm{ma}^{c}$ rifa in this passage, and hence it should only be translated as "recognition" when found in Abū l-Barakāt's writings. The idea of recognition plays a central role already in Avicenna's solution to Meno's paradox in his Healing, Demonstration I.6 (Al-šif $\bar{a}^{\supset}, A l$ manțiq, Al-burhān, ed. by A. 'Afífi, Cairo, al-Mațba' ${ }^{\mathrm{c} a}$ al-amīriyya, 1952, p. 75 1. 9 - 
(6) Knowledge ( ${ }^{c} i l m$ ), which entails providing a statement that can either correspond (muwāfiqa) or not correspond to the opinion of someone else or to the reality of the extramental object. If it does correspond, it is called truth (sidq), if it does not - falsehood ( $k a d \underline{d} b)$.

(7) Assent (tasdīq) or negative assent (takdīib), which means that someone with an idea either claims that it corresponds to the extramental or that it does not (cf. II.394-95).

The sequence of the first four stages reinforces my suggestion that the direct realism of Abu l-Barakāt is objective in nature. There is no place for a subjective element in these four stages. One becomes aware of something, becomes aware that one is aware of it and then learns the perceived by heart, together with a word that designates it. Here we are dealing with perception alone, as memorisation is an inner sense of perception. The subjective, however, appears in the fifth stage: recognition. It is properly up to me whether I correctly identify some new perceived object as the red apple I have seen before, as another red apple, or as a peach. This is why Abū l-Barakāt introduces the notions of truth and falsehood only after he establishes recognition. If I recognise something correctly, my knowledge is true. If I do not, then it is not.

Abū l-Barakāt thus denies any dualism on the level of perception. We perceive things as they are, with some individuation through senseorgans. Even if a red apple appears blue to me, the blue apple is still a piece of empirical data that is not anyhow contaminated by the interference of my subjective point of view. There is however another dualism. The dualism between a personal idea, an image saved in the mind, and the object to which this idea supposedly corresponds. This dualism is a way for Abū l-Barakāt to explain the correlation between the subjective and objective. When I see a red apple for the first time I directly learn the empirical data. When I however see the red apple for the second time, I compare the new empirical data with the saved image and may err in identifying it as red apple. Unfortunately, Abū l-Barakāt does not clarify possible reasons for a failure of recognition: if I directly learned the empirical data for "red apple" from one red apple, and I directly

p. 76 1. 13). Avicenna distinguishes between the stage of learning something without intending it (cf. Abū l-Barakāt's stages 1-4) and the intentional recognition of something as corresponding to the previous knowledge of it (cf. Abū l-Barakāt's stage 5; cf. Healing, Demonstration I.3, 58.10-18 on recognition in sense-perception). I am grateful to the anonymous reviewer for bringing my attention to this probable historical background of Abū l-Barakāt's seven levels. On Avicenna's solution of Meno's paradox see Michael Marmura, "Avicenna on Meno's paradox: On 'apprehending' unknown things through known things", Medieval studies, 71 (2009), p. 47-62. 
perceive another red apple when I intend to subsume it under the same "red apple" concept, why would I recognise the other red apple as a blue apple? Abū l-Barakāt's theory of recognition makes room for subjective mistakes but it does not explain where they come from ${ }^{26}$. Another problem concerns how other people can know the objects of my inner senses. Abū l-Barakāt argues that I can explain with words what I have on my mind to another person. This other person can then find a corresponding mental form in himself and recognise this form as the same as that which I described. Abu l-Barakât - quite intuitively - insists that the interlocutor only finds a corresponding idea in his mind. Therefore, the perception of something imaginative - mental forms - differs from the perception of something extramental because, in the latter case, the interlocutor perceives the same extramental object that I do (II.322.17 323.6). However, given all of his arguments against representationalism, how can Abū l-Barakāt avoid the idea that the interlocutor must perceive precisely the same object that is in my mind? If he does not, then he has not perceived what I mean, as Abū l-Barakāt argued above in the context of perception in general. Unfortunately, Abu l-Barakāt does not address this problem.

\section{CONCLUSION}

So far, I have argued that Abū l-Barakāt developed an epistemological theory that went beyond the boundaries of the traditional Aristotelian-Avicennian framework. Although one may equally ascribe direct realism to Avicenna and the Aristotelian tradition, Abu l-Barakāt's unified direct realism is certainly new to the tradition. The unified direct realism involves three claims:

1. the proper objects of perception are things in themselves

2. the unity of the perceiver of intelligibles and sensibles

3. the unity of the process by which intelligibles and sensibles are perceived

I cannot claim to be the first to recognise the innovative character of Abū l-Barakāt's unified epistemology. Although Abū l-Barakāt's importance has been largely neglected in contemporary scholarship, medieval

26 I am grateful to the anonymous reviewer for bringing my attention to this shortcoming in Abū l-Barakāt's theory. 
scholars of the twelfth and thirteenth centuries Islamic east were very well aware of it. We may find the following historical report in the Doubts on Avicenna's Pointers and reminders of Šaraf al-Dīn al-Mas ${ }^{\mathrm{c}} \overline{\mathrm{u}} \mathrm{d} \overline{\mathrm{l}}$, who succeeded Abū l-Barakāt by two generations (d. before 1204):

Saying that the perceiver is divided into the corporeal one which perceives sensibles only and the incorporeal one which perceives the intelligibles only is wide-spread and accepted, and most people agree on this. Nobody disagreed with them apart from the eminent of our time whom God - may He be exalted - distinguished by superiority in investigation and inquiry: this is the author of The reconsidered, [Abū l-Barakāt al-Bagiādī], may God give thanks to him for his efforts and give him a great reward! If you follow the pattern of correct judgement, leave aside [personal] inclinations and solidarity, and are not satisfied with doctrines according simply to the way they sound, then you will know that the true is that which [Abu l-Barakāt] believed ${ }^{27}$ (215.8-13).

$\operatorname{Mas}^{\mathrm{c}} \overline{\mathrm{u}} \mathrm{d} \overline{\mathrm{i}} \mathrm{s}$ historical observation aligns with my analysis in section five: Abū l-Barakāt's opposed the Avicennian tradition by rejecting a distinction between two subjects of perceptions for intelligibles and sensibles. Mas ${ }^{\mathrm{c}} \overline{\mathrm{u}} \mathrm{d} \mathbf{i}$ completely agrees with Abū l-Barakāt in what follows.

Reports of Abū l-Barakāt's radical position were not always so approving as $\mathrm{Mas}^{\mathrm{c}} \overline{\mathrm{u}} \mathrm{d} \hat{\mathrm{\imath}} \mathrm{s}$. The following account appears in the treatise Important points and useful remarks, whose authorship has not yet been identified:

Do not listen to what the Sheikh of the Jews [Abū l-Barakāt alBagdādì ${ }^{28}$ ] says, that the perceiver of these [corporeal phenomena] is the soul itself without any organ. For, first, no particular corporeal form can be impressed in the soul, but only universal intellectual form according to what will shortly be explained to you. Also, we observe the falling rain as lines and one fire when it is quickly rotated, but we do not perceive with senses anything that does not exist extramentally; hence it remains that it is internal. Its existence is not in the soul, since it requires [some] distinction from it and since no particular form can occur to it. Therefore, it remains that it is in some other internal faculty, which is called the common sense $(154.9-14)^{29}$.

Without devoting much attention to the details of Important points'

27 Quoted after Šaraf al-Dīn al-Mas ${ }^{\mathrm{c} u ̄} \mathrm{~d}, \mathrm{i}, A l-m a b \bar{a} h i \underline{i t} w a-l-s ̌ u k \bar{u} k{ }^{c} a l \bar{a}$ kitāb al-Išārāt, ed. by Ayman Shihadeh (Leiden-Boston: Brill, 2016).

28 For identification of the Sheikh of the Jews with Abū l-Barakāt see Yahya Michot, "Al-nukat wa-l-fawā’id: An important summa of Avicennian falsafa", in P. Adamson (ed.), Classical Arabic philosophy: Sources and reception (London-Turin: Warburg Institute - Nino Aragno, 2007).

29 Quoted after "Al-nukat wa-l-fawā̄id", MS Feyzullah 1217. 
critique of Abū l-Barakāt, one may notice that its author generally is not content with the claim that one can perceive sensibles directly without essential involvement of any sense-organ. We saw in the fourth section that Abu l-Barakāt's position on this point is indeed very radical.

Probably the first author to acknowledge the importance of Abū lBarakāt's theory by criticising it was his young contemporary 'Umār b. Sahlān al-Sāwī (d. 1145). In his treatise The way to sanctification he claims to have been asked by certain colleagues to react to Abū 1Barakāt's theory of God's knowledge of particulars (121). Sāwī recognises that this theory is heavily based on Abū l-Barakāt's innovative epistemology. This systematical background forces the author of The way to sanctification to spend a major part of his treatise (136-46) arguing against the following view:

All perceptions pertain to the soul alone. There is no visual power in the eye, nor any hearing power in the ear, nor smelling power in the nose, nor tasting power in the tongue, nor any touching power in the whole body of man, such that it would distinguish between coldness and hotness, wetness and dryness, hardness and softness, roughness and smoothness. Rather, all these perceptions pertain to the soul itself ${ }^{30}$ (137.13-16).

In the rest of this section, Sāwī presents Abū l-Barakāt's arguments from distances and magnitudes, as well as the first-person intuition, and attempts to give Avicennian responses to them. In general, the argument from the perception of magnitudes becomes the hallmark of Abu l-Barakāt's theory of perception for following centuries. In the end of the thirteenth century $\mathrm{Sa}^{\mathrm{c}} \overline{\mathrm{l}} \mathrm{d}$ al-Yamānī al-Tustarī (d. 1306) ascribes the following line of reasoning to Abu l-Barakāt in his treatise The debates between Rāzī and Țūsì:

When the author of The reconsidered [understood] the necessity of [positing] the impression in perception, yet he established that the impression of the large in the small is impossible, he could not but say that the perceiver of everything perceived is the soul. It [perceives] without the mediation of organs. Rather those external and internal organs are not mediators in terms of perception but [only] in terms of the specification of something perceived as opposed to the other. The perceiver is the soul without organs. He claimed that the perceived is impressed in the soul itself, so that no impression of the large in the small must follow ${ }^{31}$ (fol. 44r.14-17).

30 Quoted after "Umar b. Sahlān al-Sāwī, "Nahğ al-taqdīs", in G. Dadkhah and M. Karimi Zanjani Asl (eds), Three logical and philosophical treatises (Bonn: Goethe und Hafis, 2013), p. 119-54.

31 Quoted after Said al-Yamānī al-Tustarī, Kitāb al-muḥākamāt bayna Nașīr al-Dīn 
Tustarī also acknowledges Abū l-Barakāt's denial of the mediatory role of sense-organs. He nicely describes the subtle difference between the involvement of sense-organs as necessary conditions (Avicenna's position) and their merely supplemental role as "specifiers" in Abū l-Barakāt. That said, Tustarī's analysis does differ from mine. He thinks that Abū l-Barakāt uses the magnitudes argument in order to establish that the impressions of all perceived things inhere directly in the soul. Conversely, on my interpretation this reasoning only applies to intellection and inner sense-perception, such as imagination. As for outer sense-perception, we perceive things without any impressions at all, that is, through having a direct epistemic relation between the first-person subject of perception and the mind-independent object itself.

These passages present clear evidence that Abū l-Barakāt's theory of perception was acknowledged, both by his contemporaries and scholars in subsequent centuries, to be an important contribution and, indeed, a breakthrough in the history of epistemology. It necessitated a response, either positive or negative. While these accounts tend to emphasise the role of the unity of the perceiver in Abū l-Barakāt's theory, we have seen in section five that this unity of perceiver is interwoven with his idea of the unity of the process of perceiving. That is, whoever perceives intelligibles is identical to the one who perceives sensibles because, for Abū l-Barakāt, the same process is involved in knowing either intelligibles or sensibles. Otherwise his account would not differ at all from Avicenna's position who also accepted to an extent the unity of the subject of perception.

In respect to Abū l-Barakāt's idea of the unity of process, I would like to advance a hypothesis in the conclusion of this paper that marks the influence of Abū l-Barakāt's unified epistemology in the later tradition. One can see for instance that Abū l-Barakāt's epistemology presages two further attempts of construing epistemological theories in the 12 th century. These attempts were undertaken by the two most influential post-Avicennian philosophers: Fahr alDīn al-Rāzì (d. 1210) and Šihāb al-Dīn al-Suhrawardī (d. 1191). It suffices to note that Rāzì - as has been already noticed by Heidrun Eichner - devotes significant attention to showing that knowledge is not "the occurrence of the perceived in the perceiver" -

wa-l-imām Fah̆r al-Dīn under the title Kitāb al-muḥākamāt bayna šurrāḥ al-Išāāāt, MS Laleli 2551. 
using, among others, Abū l-Barakāt's arguments from distances and magnitudes - but is rather a relation (id̄ $f a$ ) between the perceiver and the perceived ${ }^{32}$. Such a relation holds between the perceiver - that is, the first-person subject of perception and not any additional psychic faculty ${ }^{33}$ - and the perceived regardless of what the perceived is. In his Commentary on Avicenna's Pointer and reminders, Rāzī concludes after extensive dialectical reasoning:

The truth for us is that perception does not mean the occurrence of that form alone; rather it means a relational state which obtains either between the intellectual capacity and the quiddity of the form which exists in the intellect, or between the former and the concrete thing realised extramentally (II.226.9-11).

Although Rāzì accepts that the occurrence of a form may be a part of the process of perception, his central claim is that it is not an essential part of it. Like Abū l-Barakāt, Rāzī thinks that the core of any perception consists in a "relational state" to the perceived object. While this epistemic relation may be either to intelligibles or to sensibles, the important point is that the relation is one and the same even while the objects of knowledge differ in kind.

As for Suhrawardī, whose epistemology was recently addressed by Heidrun Eichner and Jari Kaukua ${ }^{34}$, his theory that knowledge is mere "presence" (hudūr) of the perceived to the perceiver - regardless of whether it is a universal or particular - could also be construed as being indebted to Abū l-Barakāt's epistemological unified direct realism as well. As his detailed analysis in the Paths and havens ${ }^{35}$ makes particularly clear, the main aim of Suhrawardì's theory of "knowledge

32 Cf. Heidrun Eichner, “'Knowledge by presence', apperception and the mind-body relationship: Fakhr al-Dīn al-Rāzī and al-Suhrawardī as representatives and precursors of a thirteenth-century discussion", in Peter Adamson (ed.), In the age of Averroes: Arabic philosophy in the sixth / twelfth century (London: Warburg Institute, 2011), p. 117-40.

33 Rāzī specifically focuses on the unity of the subject of conception and sensation in the Commentary on Pointers and reminders, II.222.6-13 (quoted after Fahr al-Dīn alRāzī, Šarḥ al-Išārāt , ed. 'A. Nağāfzāda, 2 vol., Tehran, Anğuman-i Ātāār wa Mafāhnir-i Farhangī, 2005).

34 Eichner, "Knowledge by presence", and Jari Kaukua, "Suhrawardī’s knoweldge as presence in context", in Sylvia Akar, Jaakko Hämeen-Antilla, and Inka NoksoKoivisto (ed.), Travelling through time: Essays in honour of Kaj Öhrnberg (Helsinki: Finnish Oriental Society, 2013), p. 309-24.

35 Quoted after Šihāb al-Dīn al-Suhrawardī, Al-mašāric ${ }^{c}$ wa-l-mutārahāā, ed. by H. Corbin, Opera metaphysica et mystica, vol. 1 (Istanbul: Maarif Matbaası, 1952), p. 194-505. 
by presence" or "illumination" (išrāq) is to show that there must be some knowledge - ascribed to the first-person subject, as it was in Abu 1-Barakāt - that does not manifest through the occurrence of a form ${ }^{36}$ (485.13). Among other things, Suhrawardī argues for this by appealing to Abū l-Barakāt's argument from magnitudes (486.1-17). Suhrawardī's position is then summarised as follows:

Everything that soul perceives must be divided into [following] divisions: [1] As for universals, they are perceived through the presence of a form which is impressed in the essence of [the soul]; [2] As for particulars, they are perceived either through the presence of themselves and illumination of the soul, or through the occurrence of something in something which is present to the soul and about which the soul has illumination. So, soul perceives particulars either through their presence to it or through the presence of something which is present to it, such as imaginative forms. If there ought to be [some] investigation of this, we reserve it only for those who belong to the illumination. The whole can be summarised as that [whatever is known] is not hidden from [the soul] (487.12-17).

Suhrawardī accepts that in some cases perception involves the impression of a form in the perceiver. This is the case when one conceptualises intelligibles and imaginative forms. In the case of extramental particulars, however, sensibles directly present themselves to the firstperson subject of perception. Suhrawardī agrees with Abū l-Barakāt that the perception of mind-independent sensibles is not based on representations in sense-organs. That said, he disagrees with Abū l-Barakāt in the case of imagination: here he allows that images inhere in sense organs. When I imagine a red apple, the image of a red apple is impressed in the sense-organ. This organ in itself, as a concrete particular, is directly present to the first-person subject of perception. This theory can only hold if Suhrawardī accepts Abū l-Barakāt's suggestion that an immaterial perceiver can have direct acquaintance with a material sensible. It might be an extramental red apple or it might the sense-organ in which the image of a red apple resides. Most importantly, Suhrawardī appears to follow Abū l-Barakāt's unified direct realism: the procedure of conception is the same as the procedure of sensation; furthermore, they have one and the same subject of perception. As a final word, I would tentatively suggest that both Rāzī’s "relational state" and Suhrawardī's "illumination" or "presence" are expressions of unified direct realism; they echo Abū l-Barakāt's idea of a direct encounter between a first-person subject of perception and any given perceived object. This hypothesis,

36 Cf. Jari Kaukua, "Suhrawardì’s knoweldge as presence". 
of course, requires further analysis of Rāzī and Suhrawardī's respective epistemologies before being accepted.

Acknowledgements. This paper is a result of my work for "Heirs of Avicenna" project, generously supported by DFG. I am grateful to Peter Adamson, Jari Kaukua, Michael Noble and the anonymous reviewers for their helpful comments on the subject of this paper. I am specifically grateful to Davlat Dadikhuda, who first inspired me to study post-Avicennian epistemology from the perspective of the contest between representationalism and direct realism. 